\title{
ANY CHANCE FOR THE ENFORCEABILITY OF THE HUMAN RIGHT TO SUBSISTENCE?
}

\author{
CELIA FERNÁNDEZ-ALLER ${ }^{1}$
}

\begin{abstract}
It is not true that the idea of the right to subsistence should not give rise to much controversy. In fact, social rights are not considered as fundamental rights by everyone. The aim of this paper is to analyze whether abstract social rights - and the right to subsistence in particular-should be put in constitutions and laws and if judges should be given powers to interpret them. The philosophical foundations and the content of the right are studied and five great challenges are presented, although the most powerful one is to focus on the social and political enforceability of the fundamental right to subsistence.

Assessing the effectiveness of the right to subsistence, and the right to food particularly, is a complex issue. In the legal discourse, the question seems to be only suggested. Even when the Constitutions expressly recognize this right in some countries, its implementation faces many constraints. The progressive realization of ESC rights requires a complex interaction of policies and programs in a wide range of sectors and institutions.

The scientific method used in this work is the legal-sociological method, regarding the understanding of the rules, the lack of them, their effectiveness, etc. Several methodological techniques have been used, such as social and legal analysis, legal deduction and induction, description and interdisciplinarity.
\end{abstract}

Keywords: Economic, social and cultural rights; enforceability; right to subsistence; right to food; International Law of Human Rights

Summary: 1. The Context of Social Rights. 2. A New Social Right?. 3. Legal Foundations of The Right to Subsistence: The Case of The Right to Food. 3.1 The content of the right to food. 3.2 Enforceability. 3.3 Entitlements and duties. 3.4 Links between the right to food and other human rights. 4. THE CHALLENGES. 5. Conclusions

\section{The Context of Social Rights}

As many authors recognize (Robinson, 2004), "a timely and significant debate has begun on how nongovernmental organizations (NGOs) and other civil society actors can most effectively influence states and third party actors to progressively implement their economic, social, and cultural (ESC) rights obligations".

Among social and economic rights, the right to food is a very relevant and current issue, as "food justice emphasises hunger as a human rights issue, and underlines the

\footnotetext{
${ }^{1}$ Celia Fernández-Aller is PH.D in Law, and Lecturer at the Technical University of Madrid. She is a researcher in the Sustainable Organizations Group. She is a member of the Innovation and Technology for Development Center in Madrid (mariacelia.fernandez@upm.es).

The author would like to express her thanks to profesor Steven Greer for his helpful guidance, in informal conversations and email exchanges during the Visiting Research Fellowship she held at the University of Bristol Law School from June to October 2017, and with respect to an earlier draft of this article thereafter. The autor is also grateful to Jose Maria Medina, professor in Loyola Andalucía University.
} 
central place of grassroots organisations and small-scale producers in the realisation of fair systems" (Millner, 2017).

There is a difference between economic, social and cultural rights and civil ones concerning implementation, as the implementation of the first ones is weaker and gradual. The purpose of this paper is to define a realistic conceptual framework for these rights, which could be based in a positive legal system, always bearing in mind the influence of globalization in the process and the interrelations between them.

We could argue that the international human rights law has recognized these rights in the International Covenant of Social, Economic and Cultural Rights of 1966. But there are important limitations concerning the 'international human rights law' we can't ignore: the impact of international law upon the world has been disappointing: "In spite of this progress, however, the ICESCR remains a blunt instrument that is unlikely, alone, to bring about a rapid drop in deaths caused by hunger and malnutrition (Martin, M.A, Vivero, 2011)". The international bill of rights is nevertheless one of the finest achievements of humanity, but we must be realistic about what it can achieve ${ }^{2}$.

Some authors (Gearty, C., 2006) express this idea clearly: The phrase 'human rights' is a strong one, epistemologically confident, ethically assured, carrying with it a promise to the hearer to cut through the noise of assertion and counter-assertion, of cultural practices and relativist perspectives, and thereby to deliver truth. To work its moral magic, human rights needs to exude this kind of certainty, this old-fashioned clarity".

A very clarifying look at the realistic approach to human rights is given too (Greer, S, 2009): “Although human rights must be taken seriously and installed at the very center of the emergent global value system, realism acknowledges that they can never be fully implemented. This is not because of the innate wickedness of people, those who exercise power, or the institutions and systems within which we all live our lives. It is because determining what full implementation means will always be a matter of controversy since human rights are by nature vague, imprecise and open to competing interpretations even by those who are fully committed to them". "A feature of human rights realism is the commitment to enshrining international human rights as constitutional rights in national legal systems. But this, in its turn, raises two problems. First, it tends to turn human rights into formal legal doctrines developed by lawyers and judges more in accordance with doctrinal logic than with their underlying purpose. The second problem with the national institutionalization of human rights is that it creates huge political dilemmas about the role of judges in the legislative process".

\footnotetext{
${ }^{2}$ If we are realistic, we must accept that the Optional Protocol to the Covenant on economic, social and cultural rights has been ratified by 24 states, which turns the initial euphoria around the Optional Protocol in a really disappointing instrument to enforcing social rights.
} 
Others think the full realization of human rights is more a matter of Ethics. A good example (Paupp, 2014) argues that to be realized, rights to peace and development must be enshrined as global constitutional directive principles, rooted as much in a new global ethics as in law or politics.

Anyway, we should find the way to introduce these social rights in the domestic law system to have any chance of enforceability for them. But trying to solve most of the problems described above and from a realistic approach. And finally, maybe we have to foster imaginative systems of socio-political enforceability after assuming that the legal one is not such a useful one.

A good discipline when thinking about controversial rights is to go back to history and to first principles. The human rights ideal derives fundamentally (though not straightforwardly) from the idea of natural rights advocated by thinkers, such as Hobbes, Locke and Rousseau in the $17^{\text {th }}$ and $18^{\text {th }}$ centuries, who thought the entire catalogue of what we now think of as civil and political rights could be rationally deduced from facts of nature, particularly from the 'equal natural right to life'.

This is, of course, a controversial, and a much criticized, claim. But it can be understood based in the following ideas: If we strip away all the assumptions of culture and civilization -such as those which maintain that the rich and powerful have a stronger claim to live and to survive than anyone else- we arrive at the simple idea that, prima facie, no human baby born into the world has a stronger claim to live than any other. They each have 'an equal right to life' in other words. Now, if there is such a right, the right with which it is most intimately connected is the right to subsistence. Rather confusingly the natural rights thinkers referred to this as the 'right to property' because in order to survive we need to take ownership of nature in the most fundamental way possible - by digesting it.

But, for these thinkers all the natural rights, including the right to life, were negative rights. In other words, the obligation upon others, including state and society, was simply to refrain from interfering with them but not actively to deliver them. The right to food in this model is, therefore, the right to engage in the struggle for survival on an equal basis with others. But, apart from the 'natural obligation' upon parents to feed and to care for their children, this does not give rise to an obligation on the part of anyone else to feed other people. In settled and stable conditions the function of law and state is simply to guarantee that the struggle for survival is pursued peacefully. However, in conditions of scarcity the natural rights thinkers would have accepted those who had a surplus of food might have a charitable, moral or religious obligation to feed those with insufficient food. And the State would have an obligation to provide, at least, based in the international Human Rights Law.

The natural rights model was, of course, fundamentally altered by democratization and socialism because once everyone had the vote they could quite reasonably demand that, in return for paying taxes, the state should make provision for social security, education, health care etc. But this was limited to self-governing and self-financing political communities. 
However, since the advent of democratization, globalization has arguably created, or begun to create, a single global community. One clear result is that the richest parts of the world are rich largely because the poor parts of the world are poor (UN Special Rapporteur on the right to development, 2017).

So a global or universal 'right to subsistence' might be derived from a theory of global justice where the central argument would be that the global distribution of rights and obligations is out of balance and the rich parts of the world have political and moral obligations to do a great deal more to enhance development in poorer parts of the world.

Therefore, the 'right to subsistence' is best understood in developed societies as part of the social security obligations of states, and globally as part of the package of development rights which are held collectively by developing states. But, incidentally, the right to development can only be held collectively and it's essentially political/moral and can't be legally enforced ${ }^{3}$.

Because the processes of globalization are making the world increasingly integrated, a global right to social security may be emerging which would include a global positive right to subsistence. But this is unlikely to be effectively institutionalized until the kinds of pre-requisites which made social security possible in liberal democracies are also globalized. And what it would mean in detail and how it would be enforced present considerable challenges.

The 2030 Agenda for Sustainable Development Goals (SDG), although not containing explicitly the right to subsistence, includes the objective of eradication of hunger. If we continue advancing at the present rate and with the same efforts, we won't be able to achive the SDG, neither the realization of the human right to subsistence. The most vulnerable, as usual, will be the most disadvantaged.

The foundations of this right is clearly linked to the concept of Global Distributive Justice (Armstrong, C., 2012), especially the equalitarism (Beitz, Caney). The vast majority of theorists of global justice -whether of the minimalist or egalitarian varietyare prepared to argue for subsistence rights as part of any satisfactory account of human rights.

Whereas the minimalist accounts set their sights relatively low in aiming to secure a decent minimum for all (although this could still be a very challenging objective in practice), egalitarian accounts are less easily satisfied. Even if everyone's basic needs were met, they would still offer reasons to be uneasy about the inequalities which might remain. In fact, we could object to global inequalities for a wide range of reasons, and different egalitarian theories will pick out different reasons on which to focus.

\footnotetext{
${ }^{3}$ Anyway, the United Nations Human Rights Council, in resolution 33/14, adopted on 29 September 2016, decided to appoint a Special Rapporteur on the right to development. According to the resolution, the Special rapporteur's mandate includes: Contributing to the promotion, protection and fulfilment of the right to development in the context of the implementation of the 2030 Agenda for Sustainable Development.
} 
Egalitarians frequently tell us that the degree of inequality at the global level is immense. Charles Beitz, for instance, tells us that 'We live in a world whose massive inequalities dwarf those found within the domestic societies familiar to us'. Darrel Moellendorf observes that 'Our world is marked by deep and pervasive inequalities'. Simon Caney tells us that "The world that we inhabit is characterized by staggering inequalities'. Here Beitz, Moellendorf and Pogge apparently agree that global inequalities are profound, and morally serious. All of them defend four principles: everyone has a human right to subsistence; one should prioritize improving the position of the worst; equal pay for equal work; global equality of opportunity.

Finally, one powerful reason for defending the right to subsistence is the opinion of people who is starving (Smith-Carrier, T.; Ross, K.; Kirkham, J. and Decker Pierce, B., 2017). As the Committee on Economic, Social and Cultural Rights highlights: The real potential of human rights lies in its ability to change the way people perceive themselves vis$\grave{a}$-vis the government and other actors (Committee on Economic, Social and Cultural Rights).

\section{A New Social Right?}

Reluctance to accord economic, social and cultural rights the same level of recognition and enforceability affects disproportionally the most vulnerable members of society. It is a fact that economic, social and cultural rights don't have the same enforceability as civil and political ones. They have been considered more a matter of policy than fundamental rights.

Some arguments against constitutional social rights are that courts can not adjudicate positive rights (although in practice, they do); that this would violate the separation of powers; that social rights are too vague and conflict with each other (as civil and political ones...).

A deep analysis of the literature reveals that more and more academics are starting to pay attention to social rights and finding new ways of enforceability (Ssenyonjo, M., 2016). Courts, as well, are moving towards a more open vision of these rights:

"Historically, the attitude of the state towards the poor, the elderly and the incapable has not been uniformly benign. But for the past 60 years or so it has been recognised as the ultimate responsibility of the state to ensure that [the sick, elderly and disabled] are accommodated and looked after through the agency of the state and at its expense if no other source of accommodation and care and no other source of funding is available. This is not a point which admits of much elaboration. That the British state has accepted a social welfare responsibility in this regard in the last resort can be hardly a matter of debate" (King, 2012).

Social rights should be understood as rights to a social minimum. This can be explained as follows: there are, however, many objections to constitutional social rights, which are outlined by King in the first chapter of Judging Social Rights: a) Firstly, judicially enforced social rights might seem to lack democratic legitimacy. As King notes, nearly all 
of us pay into and take out of the public system. There could therefore hardly be a better scenario in which the voice of each should count equally which would suggest that the appropriate forum for resolving disputes involving resource allocation is the legislature, not the courtroom. To this we might add that even if the welfare state is a settled feature of most liberal democracies, it remains the case that reasonable disagreement about the nature and extent of the state's welfare obligations constitutes a key political fault line. Constitutional social rights might therefore threaten to remove important and contested issues from the political process to the hands of unelected judges; b) Secondly, the legal philosopher Lon Fuller coined the term 'polycentricity' to describe issues that he regarded as unsuitable for adjudication on the basis that they involve a vast number of interconnected variables. Fuller famously employed the metaphor of a spider's web to describe problems where a decision on one issue - or a pull on one strand of the webwill have far-reaching and unforeseeable consequences. Fuller's point was not that such problems are incapable of resolution but rather that - with their reliance on an adversarial procedure typically involving two parties - are inappropriate forums for the resolution of polycentric issues, given that the full range of affected parties will not normally be represented. The allocation of scarce resources amongst competing needs would seem to be a paradigmatic example of a polycentric problem, given that a decision to allocate resources to a particular party will frequently have complex repercussions for other parties; c) Thirdly, many decisions relating to social rights - for example, whether a particular drug is safe - would seem to involve considerable expertise not typically possessed by judges; d) Fourthly, there is a clear need for flexibility in the provision of social rights because of the possibility of unforeseen information or changing circumstances. Courts, with their capacity to issue binding orders subject to a system of precedent, might threaten to introduce an unwelcome element of rigidity into the welfare state. All of this leads King to characterise the constitutionalization of social rights as a risky enterprise (Wesson, 2012).

Jeff King has an interesting theory called incrementalism, which can help in this context. Courts should adopt an "incrementalist" approach to social rights adjudication. By incrementalism King means that courts should avoid judgments that generate significant, nationwide allocative impact. Courts should instead give decisions on narrow, particularised grounds or, where far-reaching implications are unavoidable, decide cases in a manner that preserves flexibility. It follows that judicial decision-making should ordinarily proceed in small steps, informed by past steps, and small steps might affect large numbers of people, but in ways that preserve latitude for adaptation.

There is quite a big consensus around the idea that the right to subsistence is, as well as physical security and liberty, a basic right. That is, a moral minimum (King's social minimum ${ }^{4}$ ), things which every human being will need in order to live a life of any appreciable quality. It consists of the right to unpolluted water, adequate food, shelter, clothing, minimal preventive health care. We understand these rights are absolutely fundamental for anyone's chances of a minimally decent life. This right to subsistence is recognized in article 11 of the International Economic, Social and Cultural Rights Covenant.

\footnotetext{
${ }^{4}$ The role of the courts is to play a subsidiary but nevertheless important role in securing the social minimum in cooperation with the other branches of government.
} 
The right to subsistence can be understood as a fundamental human right in the internationalist sense, as ius cogens based in the article 4 of the International Covenant on Civil and Political Rights. But it is fundamentally a negative and conditional one. If we have the physical and mental capacity to do so, we have the obligation to labour to survive. The state does not have the unconditional obligation to provide us with subsistence. In other words: 'From each according to their ability. To each according to their legitimate needs.' The state has, of course, a duty to develop social policies ensuring a conducive environment in which anyone can have a job.

We think that there are such things as social and economic rights. At the international level they exist as political and moral claims, but there are legal duties established at the international enforceable laws, such as the Economic, Social and Cultural Rights Chart. While they are, of course, part of 'international human rights law', this lacks two of the most important characteristics of positive law - legislation and effective judicializationwhich give law the capacity to make a significant direct difference to people's lives.

At the domestic level social and economic rights are partially justiciable. Even in states where they are as firmly legally institutionalized as possible, the most that courts and lawyers do is to remind public authorities genuinely to take them into account. This is because judges do not usually think they have neither the democratic legitimacy nor the technical know-how to decide upon which social and economic priorities tax revenue should be spent. It would be useful to give courts some powers to correctly interpret social rights. The road to do so is just starting.

There is a need to create and to sustain social and political conditions that help these rights to be respected, protected and fulfilled, at home and abroad.

Lawyers and courts have different professional responsibilities domestically and internationally. Domestically, they should strive to ensure that positive national law is interpreted and applied in a rights-sensitive manner. And internationally, they should act ethically, particularly in managing the affairs of multinationals (MNCs), eg they should not be involved in designing tax avoidance schemes which enable MNCs to collude with corrupt elites to strip the assets of poor nations, locking them into long-term underdevelopment.

Many authors don't agree with the idea of recognizing new human rights, as the more the distinction between 'human' and 'other kinds' of right is blurred the more difficult it becomes to establish an appropriate hierarchy and to settle conflicts between rights. Rather than expanding the catalogue of human rights (Brysk, 2017), they think it would be better if the ones we have already were better respected and enforced. All injustices can be addressed within the current human rights framework rather than in terms of new human rights. Re-framing newly discovered injustices in terms of new human rights won't necessarily take us any closer to their realisation. If we focus in the right to subsistence, it would be better to introduce it in the domestic law rather than fighting for new rights as the right to development, or the right to solidarity, which could help achieving the right to subsistence. 
The most effective and democratically acceptable way to promote economic and social rights is a political process, while courts have the task of enforcing legislative decisions and holding the political branches accountable through already existing mechanisms, such as control of procedure and the examination of reasonableness and non-discrimination in administrative decision-making.

The political process has been particularly important in the origin, for example, of the right to water. The water justice movement, not directly linked to the human rights one, has been extraordinary active in the social enforceability of this right. This social movement is needed now to push the achievement of the right to subsistence, and particularly, the right to food ${ }^{5}$.

\section{Legal Foundations of The Right to Subsistence: The Case of The Right to Food}

We are focusing on one of the elements of the right to subsistence, as it is a wide range one. This is the right to food, with has main international instruments that constitute or develop it:

- The Charter of the Organization of American States, article 34: "States likewise agree to devote their utmost efforts to accomplishing the following basic goals: ...j) Proper nutrition, especially through the acceleration of national efforts to increase the production and availability of food";

- Universal Declaration of Human Rights: Article 25 " Everyone has the right to a standard of living adequate for the health and well-being of himself and of his family, including food, clothing, housing and medical care and necessary social services, and the right to security in the event of unemployment, sickness, disability, widowhood, old age or other lack of livelihood in circumstances beyond his control"

- International Covenant on Economic, Social and Cultural Rights, article 11: 1. The States Parties to the present Covenant recognize the right of everyone to an adequate standard of living for himself and his family, including adequate food, clothing and housing, and to the continuous improvement of living conditions. In paragraph 2 of article 11: "the fundamental right of everyone to be free from hunger" is recognized.

Article 11, especially the right to food, has been interpreted by the UN Committee on Economic, Social and Cultural Rights in its General Comment No. 12, from 1999. The committee mainly interprets the State obligations that derive from the right to food, the principles that govern it, its normative content, the steps which States should

\footnotetext{
${ }^{5}$ This is one of the most powerful lines of research of the Observatory for the Right to Food in Spain, which has been created recently : https://www.derechoalimentacion.org/
} 
take to achieve national implementation and States what constitutes a violation of the right.

Other international agreements in addition to basic instruments that are also binding and yet more specific have recognized the right to food within its normative body as a human right that generates obligations for States:

- The Convention on the Elimination of All Forms of Discrimination against Women - CEDAW

- The Convention on the Rights of the Child - CRC

- International Convention on the Protection of the Rights of All Migrant Workers and Members of Their Families -ICRMW

- Indigenous and Tribal Peoples Convention, 1989

- $\quad$ Rome Statute

The right to food is also recognized in various declarations:

- Universal Declaration on the Eradication of Hunger and Malnutrition, 1974, which literally reads "very man, woman and child has the inalienable right to be free from hunger and malnutrition in order to develop fully and maintain their physical and mental faculties."

- Declaration on the Rights of Disabled Persons, 1975

- Convention on the Elimination of All Forms of Discrimination against Women, 1979

- Declaration on the Right to Development, 1986

Equally, the right to food -or some of its aspects- has been recognized at multiple international summits and reinforced in the corresponding final documents, including:

- Universal Declaration of Hunger Erradication 1974

- Declaration of Principles and Programme of Action of the World Conference on Agrarian Reform and Rural Development, 1979

- The Declaration on the Rights of the Child, 1989, which recognizes the right of each child to a standard of living adequate for its physical, mental, spiritual, moral and social development. 
- $\quad$ World Summit for Children, 1990

- $\quad$ First International Conference on Nutrition, 1992, Second International Conference on Nutrition 2012, the Declaration and Programme of Action of the Vienna World Conference on Human Rights, 1993, the Copenhagen Declaration and the Programme of Action of the World Conference for Social Development, 1995

- $\quad$ The World Conference on Women, Beijing, 1995

- $\quad$ The Declaration of Rome for World Food Security, 1996

- $\quad$ The Plan of Action of the World Food Summit, 1996, as well as later meetings WFS +5 in 2002 and WFS +10 in 2006

- The Voluntary Guidelines to support the progressive realization of the right to adequate food in the context of national food security, adopted by the FAO in 2004 .

The Voluntary Guidelines, the primary source for this monitoring tool, were adopted by the member States of the FAO in 2004. The Guidelines reiterate the legally binding standards already existing for the right to food in the sources mentioned above, focusing on how States can fulfil their general obligation to progress towards the full realisation of the right to food as soon as possible, in the development, implementation and monitoring of its public policies.

\subsection{The content of the right to food}

There is an implicit message in the UN FAO Voluntary Guidelines that the right to food is about 'democracy, good governance, human rights and the rule of law' (FAOVGs, 2005), in other words, ensuring public accountability for protecting the Social Contract. We are all 'rights holders' with the state as the 'primary duty bearer' for ensuring food security for all. Given that food is a market commodity, more profoundly it is a public good to which all have right of access (Vivero Poh, Ferrando, De Schutter, Matei, 2018).

When dealing with the right to food we have to consider the importance of the human rights approach. There are lots of literature around its legitimacy and its contribution to the fight for the full realization of human rights (Fernández-Aller, 2008).

Article 11 of the International Covenant on Social, Economic and Cultural Rights and General Comment $12^{6}$ have defined the right to food. Though often misconstrued as a right not to starve, is in fact an inclusive right to an adequate diet providing all nutritional

${ }^{6}$ GC 12 (1999) General Comment 12, UN Committee on Economic, Social and Cultural Rights Right to Adequate Food (Article 11) E/C.12/1999/5. Available at http://www.refworld.org/pdfid/4538838c11.pdf. 
elements an individual requires to live a healthy and active life, and the means to access them.

One of the best definitions of the right to food can be find here: Ziegler J., Golay C., Mahon C., Way SA. (2011) The Definition of the Right to Food in International Law. In: The Fight for the Right to Food. International Relations and Development Series. Palgrave Macmillan, London. https://doi.org/10.1057/9780230299337_2. Another recent reference are: Naomi Hossain, N.; Lintelo, D.; Wanjiku Kelbert, A. (2019) "A Common Sense Approach to the Right to Food", Journal of Human Rights Practice, Volume 10, Issue 3, November 2018, Pages 367-387, https://doi.org/10.1093/jhuman/ huy028. Published: 09 January 2019. EIDE, A. (1995) "The Right to an Adequate Standard of Living including the Right to Food", in Economic, social and cultural rights (Asbjørn Eide, Catarina Krause \& Allan Rosas eds).

A complete definition with a very deep study of the state's duties in relation with the right to food can be found here: Oshaug, A.; Barth, W. and Eide, A. (1994) "Human rights: a normative basis for food and nutrition-relevant policies" Food Policy 199419 (6) 491-516.

The Special Rapporteurs and General Comment 12 have agreed the categories and principles.

The content has the following categories: Availability, physical and geographical accessibility, adequacy, stability-sustainability. The principles are sustainability, participation, accountability, non discrimination and equality, empowerment, human dignity and the rule of law.

The Committee considers that the core content of the right to adequate food implies the availability of food in a quantity and quality sufficient to satisfy the dietary needs of individuals, free from adverse substances, and acceptable within a given culture; The accessibility of such food in ways that are sustainable and that do not interfere with the enjoyment of other human rights.

Dietary needs implies that the diet as a whole contains a mix of nutrients for physical and mental growth, development and maintenance, and physical activity that are in compliance with human physiological needs at all stages throughout the life cycle and according to gender and occupation. Measures may therefore need to be taken to maintain, adapt or strengthen dietary diversity and appropriate consumption and feeding patterns, including breastfeeding, while ensuring that changes in availability and access to food supply as a minimum do not negatively affect dietary composition and intake.

Free from adverse substances sets requirements for food safety and for a range of protective measures by both public and private means to prevent contamination of foodstuffs through adulteration and/or through bad environmental hygiene or inappropriate handling at different stages throughout the food chain; care must also be taken to identify and avoid or destroy naturally occurring toxins. 
Cultural or consumer acceptability implies the need also to take into account, as far as possible, perceived non-nutrient-based values attached to food and food consumption and informed consumer concerns regarding the nature of accessible food supplies.

Availability refers to the possibilities either for feeding oneself directly from productive land or other natural resources, or for well-functioning distribution, processing and market systems that can move food from the site of production to where it is needed in accordance with demand.

Accessibility encompasses both economic and physical accessibility: Economic accessibility implies that personal or household financial costs associated with the acquisition of food for an adequate diet should be at a level such that the attainment and satisfaction of other basic needs are not threatened or compromised. Economic accessibility applies to any acquisition pattern or entitlement through which people procure their food and is a measure of the extent to which it is satisfactory for the enjoyment of the right to adequate food. Socially vulnerable groups such as landless persons and other particularly impoverished segments of the population may need attention through special programmes.

Physical accessibility implies that adequate food must be accessible to everyone, including physically vulnerable individuals, such as infants and young children, elderly people, the physically disabled, the terminally ill and persons with persistent medical problems, including the mentally ill. Victims of natural disasters, people living in disaster-prone areas and other specially disadvantaged groups may need special attention and sometimes priority consideration with respect to accessibility of food. A particular vulnerability is that of many indigenous population groups whose access to their ancestral lands may be threatened.

\subsection{Enforceability}

We have examples of recognition at the domestic level in the Constitutions of Bielorrusia, Bolivia, Brasil, Colombia, Congo, Costa Rica, Cuba, Ecuador, Guatemala, Guyana, Haití, Honduras, Kenia, Malawi, México, Moldavia, Nepal, Nicaragua, Panamá, Paraguay, Sudáfrica, Suriname, Ucrania (Knuth, Vidar, 2011).

There are different types of constitutional recognition of the right to food: the explicit and direct recognition of the right to food; the right to food as a right implicit in a broader human right; Directive principles of state policy; indirect recognition through interpretation of other human rights.

There are also standards about access to resources to feed one-self or on food security in specific laws, such as agrarian reform, land use planning laws, fishing laws, consumer protection laws, child protection laws, amongst others that regulate diverse aspects of the right to food. Regarding this subject, the incorporation of the right to food into national legal systems in different normative hierarchies allows judges to apply 
the decision in cases and allows lawyers and civil society in general to appeal for its application in order to demand the full realization of the right to food.

At the European level, the right to food is absent from every constitution; only Lombardía has passed a Law on the right to food, although it has not been able to achieve an acceptable level of enforceability.

It is difficult, at the European level, to have the right to food recognized by judges. A deep analysis can be found here: Vid. B. Wernaart; B. van der Meulen (*) (2016). The Right to Food in International Law with Case Studies from the Netherlands and Belgium. Springer International Publishing Switzerland. G. Steier, K.K. Patel (eds.), in International Food Law and Policy, DOI 10.1007/978-3-319-07542-6_4.

We found also some examples (Zambrano, 2019) at the judicial level (domestic, regional or international ones), with cases defended in courts all around the world (Argentina, Canadá, Sudáfrica, India, Turkey ...). For example, the decision of the Supreme Court of India in both Kishen Pattmayak and another State of Orissa and People's Union for Civil Liberties v. Union of India and others, has recognized the right to food under the right to life stipulated in article 21 of the Indian Constitution, with reference also to the Directive Principle of State Policy concerning nutrition, contained in article 47. Interim orders in the latter case have led to new and better implemented government programmes and have asserted that benefits under these programmes are legal entitlements. Such programmes include mid-day meals for school children, food entitlements in childcare centres, subsidized food for a number of specific vulnerable groups, as well as changes to the subsidies directed at all persons below the official poverty line.

Enforceability must be considered as a three level system: social, political and legal.

The legal level must consider the legislation and the International courts, Regional Courts, Domestic courts, NIHR (National Institutions of Human Rights). This has been a successful way of realizing rights through History, but it is not the only nor the most effective one.

In that sense, some (Goig Martínez, 2018) have studied the enforceability of the right to food in Spain, based in the right to health.

The socio-political level must consider the United Nations mechanisms (CESCR reports, EPU, Voluntary Guidelines, etc.), Optional Protocol, and the political pressure by citizenship, among others. The social enforceability of the right to food is very important, as in cases where rights cannot be enforced through the courts, they can be asserted through other democratic means, based for instance on parliamentary interventions, the electoral process, the media, international solidarity, street action, or even civil disobedience. This process has worked relatively well with respect to one specific aspect of the right to foodthe prevention of famines. As Amartya Sen has noted, in a democratic political system, allowing a famine to develop would be political suicide for the party in office. 


\subsection{Entitlements and duties}

In its doctrine the UN Committee on Economic, Social and Cultural Rights has recognized two kinds of obligations for states deriving from economic, social and cultural rights:

1. Obligations of general legal character, which are general obligations of immediate application and are:

a. The obligation to take steps towards the progressive realization of the right to food using the maximum of resources available, in accordance with article 2.1 of the Covenant, with the Committee's General Comment No. 3 and No. 12, contains the legal duty to move as expeditiously as possible towards the realization of the right to food.

According to General Comment No.9 the obligation to take steps using all appropriate means includes legislative means and any other means necessary for the realization of the right to food. This includes administrative, judicial or quasi-judicial remedies.

It is necessary to note that the principle of "progressiveness" means that regressive action is prohibited - the State should not adopt regressive measures that affect the realization of the right to food (Warwick, 2016).

b. Obligation to ensure non-discrimination: States should immediately guarantee that no individual is a victim of discrimination with regard to the right to food or productive resources on the grounds of race, colour, sex, language, age, religion, political or other opinion, national or social origin, economic position, birth or other status with the purpose or effect of nullifying or impairing the equal enjoyment or exercise of economic, social and cultural rights constitutes a violation of the Covenant.

c. Obligation to ensure international cooperation: this entails the obligations of developed States to support other, less developed, States who lack the sufficient resources in their fulfilment of the obligation to fulfil the right to food.

2. Legal obligations of specific character:

This is another great challenge. The Maastricht Guidelines on Violations of Economic, Social and Cultural Rights (later reissued as UN document E/C.12/2000/13), offered guidance across the full range of rights listed in the Covenant. The Maastricht Guidelines stated in paragraph 6:

Like civil and political rights, economic, social and cultural rights impose three different types of obligations on States: the obligations to respect, protect and fulfil. Failure to perform any one of these three obligations constitutes a violation of such rights. The obligation to respect requires States to refrain from interfering with the enjoyment 
of economic, social and cultural rights. Thus, the right to housing is violated if the State engages in arbitrary forced evictions. The obligation to protect requires States to prevent violations of such rights by third parties. Thus, the failure to ensure that private employers comply with basic labour standards may amount to a violation of the right to work or the right to just and favourable conditions of work. The obligation to fulfil requires States to take appropriate legislative, administrative, budgetary, judicial and other measures towards the full realization of such rights. Thus, the failure of States to provide essential primary health care to those in need may amount to a violation.

A former United Nations (UN) Special Rapporteur on the Right to Food has argued that, although the primary obligation to realize this particular ESC right rests with national governments, governments also have 'extra national obligations' to respect, protect and facilitate the right to food. He asserts that the duty to respect extends to actions that have a negative impact on people in other countries. Accordingly, a country must refrain from imposing food-related sanctions or embargoes and must ensure that its trade policies and relations do not violate the right to food of people in other countries. Under the duty to protect, a 'host' State must protect individuals against the harmful activities of TNCs investing and operating in that State. The former Special Rapporteur adds that 'home' States also have a duty to prevent violations by their companies and corporations operating abroad. The obligation to facilitate has also been interpreted to require States to build a social and international order in which the right to food can be fully realized. In part this requires that States "take account of their 'extra-national obligations' in their deliberations in multilateral organizations, including the IMF [International Monetary Fund], World Bank and the World Trade Organization (WTO)" (Narula, 2013).

Broadly speaking, the right to food can be interpreted as a claim of individuals on society (starting but not ending with the state). It is an entitlement to be free from hunger, which derives from the assertion that the society has enough resources, both economic and institutional, to ensure that everyone is adequately nourished. However, difficulties arise as soon as we try to flesh out this broad definition and translate it into specific entitlements and responsibilities. The term 'freedom from hunger', for instance, lends itself to several interpretations: getting two square meals a day, meeting specific calorie norms, avoiding nutrition-related ailments, and so on. Ideally, the right to food should be seen as a right to 'nutrition'. However, good nutrition itself depends in complex ways on a wide range of inputs: not just adequate food intake but also clean water, basic health care, good hygiene, and so on. Even if we confine our attention to food intake, the constituents of good nutrition are a matter of debate among nutritionists. For instance, there is some controversy about the importance of various 'micronutrients' for good nutrition. For all these reasons, it is hard to translate the right to food into a specific list of entitlements.

Similar difficulties arise in clarifying the responsibilities associated with the right to food. The primary responsibility is surely with the state, because the state alone commands the resources (economic and institutional) required to protect everyone from hunger, and because the state is generally responsible for safeguarding constitutional rights. However, the right to food is not the responsibility of the state alone. To illustrate, 
suppose that I come across someone who is dying of starvation on the street. If I am able to do something about it, and if I recognize that every citizen has a right to be free from hunger, it would clearly not be right for me to wash my hands of the situation and say that it is the responsibility of the state. The fact that the state bears the primary responsibility (based in the international framework of legislation) for letting this happen does not absolve me from the moral duty of intervening, if I am in a position to do so. In other words, in some circumstances at least, the responsibility for protecting the right to food is a shared responsability, involving not only the state but also other institutions or individuals.

To take another example, suppose that a girl is undernourished because she does not get a fair share of food within the family. Clearly, her right to food would be violated. But who is responsible? At some level, state responsibility would be involved, since the state has an overarching duty to eradicate social discrimination. But surely, the girls' parents (or whoever controls the distribution of food within the family) would also bear a substantial part of the responsibility for this situation. Here again, there is a difficulty in apportioning responsibilities for protecting the right to food.

Finally, other non-state actors could have responsabilities over the violation of the right to food. For example, private companies (Martin, J. and Bravo, K., 2016), in some cases. But of course, the State has the duty to protect, which means the duty to pass regulation to avoid the violation of the right to food from anyone (including companies).

\subsection{Links between the right to food and other human rights}

If the right to food is to be achieved, it needs to be linked with other economic and social rights, such as the right to education, the right to work, the right to information, and the right to health. These economic and social rights complement and reinforce each other. Taken in isolation, each of them has its limitations, and may not even be realizable within the present structure of property rights. Taken together, however, they hold the promise of radical change in public priorities and democratic politics.

There are, also, three facts that are striking about global hunger:

- First, hunger is the result of poverty, and not of there being too little food produced. Indeed, the number of the hungry has risen at the same time that the levels of aggregate cereals production are breaking record after record, and despite the fact that, on a worldwide basis, increases in annual grain production consistently exceeded demographic growth.

- Second, the majority of the hungry live in rural areas and depend on smallscale farming for their subsistence: the reason why poverty in the rural areas remains so widespread is because the kind of farming they practice has not been supported as it should. 
- $\quad$ Third, climate change, which translates in more frequent and extreme weather events such as droughts and floods and less predictable rainfall, is already having a severe impact on the ability of certain regions and communities to feed themselves, and it is destabilizing markets. The challenge before us, then, is not simply how to produce more food. It is how to produce food in ways that increase the incomes of the poorest producerssmallholders in developing countries who often work in difficult environments and lack access to high-quality soil and irrigation systems. And it is to produce food in ways that build the resilience of agriculture to climate change. This requires more diversity on farms and more crop heterogeneity. Because of the "portfolio effect" it allows, diversity of species mitigates risks from extreme weather events, as well as from the invasion of new pests, weeds and diseases, that shall result from global warming.

"It is against this broader background that the relationship between the right to adequate food and the right of everyone to enjoy the benefits of scientific progress and its applications, as guaranteed by the Universal Declaration of Human Rights and the International Covenant on Economic, Social and Cultural Rights, should be assessed. There is a natural tendency to think of these rights as mutually supportive and, in particular, to see scientific progress - and the right of farmers to enjoy the benefits of its applicationsas a condition of food security (De Schutter, 2011)".

\section{The Challenges}

The human right to food has many challenges, some of them can be the following:

1. The Food and Agriculture Organization (FAO) recognizes that the situation is going worse for food security and food sovereignty (FAO, 2017). There is clearly a situation of violation of human rights of millions of people. This is one of the most urgent challenges for humanity. If we consider the right to food as a human right, all States have obligations which an individual person or group of them can enforce. There are some tribunal resolutions related to the human right to food, mainly at developing countries (Golay, 2009). In this sense, there's still a long way to go. It has been studied deeply the potential of social rights in the European Court of Human Rights (Carmona Cuenca, 2017).

2. We must be realistic about human rights. Global ethics must be a better strategy than only law. There is a clear need of reinforcing the culture of human rights, not only the law perspective. Both are necessary. In fact, human rights issues dominate the ethical agenda at the national and international level.

An example on how to understand the global ethics of the right to food is the creation of National and International Observatories of the Right to Food ${ }^{7}$, a FAO initiative which is giving good results.

\footnotetext{
${ }^{7}$ ODA-ALC and ODA-E, the Latin American and Spanish Observatory of the right to food. Vid. https:// derechoalimentacion.org/ and http://www.oda-alc.org/
} 
There have been a proposal to create a legally binding Convention on the Eradication of Hunger and Malnutrition (Martín, M.A and Vivero, J.L (2011).

"This could enable seriously committed governments to translate their existing "soft" global commitments into "hard" time-bound national commitments (for which they would be held accountable), that would be reflected in their national legislation, policies, plans and budget; link the commitments of developing country parties to embark on defined comprehensive long-term programmes to end hunger and malnutrition no later than 2025 with commitments by donor country parties to assist in funding their programmes and in providing technical cooperation services in a predictable manner over a long term; provide a framework for South-South cooperation between developing countries for sharing experience, providing reciprocal assistance and assessing each other's plans and programmes; oblige signatory countries to avoid actions which could damage the efforts of other participating countries towards the eradication of hunger and malnutrition, and put in place procedures for handling disputes; offer a forum within which ratifying countries could agree on mutually acceptable strategies to be adopted in international negotiations that have a potentially significant effect on the incidence of hunger and malnutrition, especially those related to food trading, regulation of extreme instances of market speculation and monopolistic behaviour, non-conversion of prime farm land to nonagricultural use, safe global food stock levels, population, small-scale farming oriented agricultural research and the sustainability of natural resource use; support the creation and implementation at national and global levels of real-time systems for monitoring delivery on commitments 51 and progress towards the goal adopted by the Convention; recognize and reward institutions for outstanding contributions towards achieving the goal, and bring the failure by any state party to honor its commitments to the attention of the Conference of the Parties, and put in place procedures requiring them to remedy the situation".

From our realistic approach to human rights, this proposal could not be supported. New international treaties are not a good way of achieving enforceability of the right to subsistence.

3. There is a challenge related with accountability, which is very important. With limited enforceability, that's difficult to get. More accountability can be achieved not only through courts, but through the United Nations mechanisms, such as the Universal Periodic Review and Optional Protocol to the Economic, Social and Cultural Rights. Another enforceability system are the National Human Rights Institutions (FernándezAller, 2014), which have been traditionally focused in civil and political rights.

4. The role of non state actors must be reconsidered: a state based approach is not effective in the era of globalization, obviously. The power and influence of MNC is higher than most states, and so is the possibility to impact in human rights.

Non state actors have obligations to prevent and redress corporate-related human rights violations under the European Convention for the Protection of Human Rights and 
Fundamental Freedoms. We must consider that the evolving jurisprudence of the European Court of Human Rights allows the application of international human rights obligations to non-state actors (the public-private divide) and the jurisdictional scope of international human rights treaties (the territoriality-extraterritoriality). The case law of the European Court of Human Rights (ECtHR) defines two categories of State obligations: negative obligations to respect human rights in relation to corporations acting as state agents; and positive obligations to protect human rights in relation to corporations acting as third parties. There is a growing body of case law on the extraterritorial dimension of the human right to remedy, which remains a pressing concern in the business and human rights domain (Augenstein \& Lukasz Dziedzic, 2017).

The existing human rights legal framework is not a good tool to deal with violations committed by non state actors, such as transnational corporations (TNCs), and multi-state actors, such as International Financial Institutions. International Law is in need of rethinking under globalization, and the right to food can help (Narula, S., 2006, 2013).

A very good example of how non state actors are liable and responsible in relation with the right to food is the case of intellectual property rights and companies: "in exercising and enforcing their intellectual property rights, agricultural companies should not disrespect the right to food by making it difficult for farmers to gain access to the means of food production. What this means in concrete terms is that agricultural companies should not engage in activities that negatively impact the non-commercial farmers' seed system such as the aggressive marketing of GMO seeds with the goal of stifling the existence of the farmers' seed system in a country. In addition, in situations where farmers are dependent on patented seeds, agricultural companies that own these patented seeds should not sell these seeds at exorbitant prices nor should they prevent farmers from saving and exchanging seeds" (Oke, 2020).

5. Economic, social and cultural rights are difficult to deliver, the extent or content is not agreed and it is difficult to enforce them. We need to create social and political conditions that help these rights respected, protected and fulfilled. A very important task for law professionals would be to foster the inclusion of these rights at the domestic level (both at the constitutions, and at the domestic legislation). The proposal of a World Court of Human Rights is not considered a realistic one, because it wouldn't be enforceable until the states should decide to.

While human rights may be justiciable internationally, this does not make them effectively enforceable for two main reasons: international human rights courts tend to be highly selective in the cases they hear and states can usually negotiate with each other what compliance with their judgments means or simply ignore them with little or no adverse consequence.

The best prospects for any human right are to institutionalize it in the political and civic culture of national liberal democracies and in their constitutional systems where the judgments of independent, rights-minded, professional and accessible courts are respected by other public institutions, and where a genuinely free press and other civil society institutions can bring alleged violations to public attention. 
But socio-economic rights tend to be only 'partially justiciable' at best because their fulfilment depends upon the distribution of public resources which is inescapably political. However, the right to food is probably more justiciable than, for example, the right to adequate health care or education, since it's so fundamental to life and because there is less scope for what counts as effective realization.

Among the socio-political enforceability to achieve the right to food, there are two very powerful issues: Milan Urban Food Policy Pact ${ }^{8}$ and the Basic Income (Valledor, 2013). We can only highlight the importance now, and let more deepening for future contributions.

The Milan Urban Food Policy Pact (MUFPP) was announced in February 2014 at the C40 Summit in Johannesburg, where the Mayor of Milan launched the proposal for a Pact to be signed during the forthcoming Expo 2015. The Milan Urban Food Policy Pact was signed on the 15 October 2015 in Milan by more than 100 cities and presented the day after to the UN secretary general Ban Ki-moon on the occasion of the World Food Day celebration.

Some of the recommendation actions are related to Governance, Sustainable diets and nutrition, Social and economic equity, Food production, Food supply and distribution and Food waste.

Concerning food supply, the text recognizes: "Review public procurement and trade policy aimed at facilitating food supply from short chains linking cities to secure a supply of healthy food, while also facilitating job access, fair production conditions and sustainable production for the most vulnerable producers and consumers, thereby using the potential of public procurement to help realize the right to food for all."

Finally, we must consider that this proposal of striving the socio-political enforceability needs background political conditions: Courts operate on a model of common law it is not likely to change radically; there are reasonably independent courts that are not party political; the legislature is elected by universal franchise; there are substantial non-judicial or specialized adjudicative accountability mechanisms (tribunals, ombudsmen, etc); there is a good-faith political commitment to protecting social rights, a reasonably good welfare state; disproportionate political and economical power is not held by wealthy groups (major enterprises); there is a reasonably independent, professional, well functioning non corruptive civil service (King, 2012).

\section{Conclusions}

A deep reflection on the compliance and respect of the right to subsistence in general, and the right to food in particular, gives us a pessimistic result. Although these rights have solid philosophical foundations, there is still a long road to go in relation with

\footnotetext{
${ }^{8} \mathrm{http}: / /$ www.milanurbanfoodpolicypact.org/
} 
the enforceability of them. The International Law of Human Rights establish clearly the content of the right to food, and the procedure for the legal enforceability. But the big violation of the right to food around the world and the difficulties to reach the Sustainable Development Goal number 2 show that there are many challenges when it comes to enforceability, especially the socio-political one. The text has made a summary of some of the most promising areas of socio-political enforceability: the United Nations procedures, the public policies such as the Milan Urban Food Policy Pact, and the enforceability of non-state actors such as companies.

\section{BiBLIOGRAPHY}

AUGENSTEIN \& DZIEDZIC (2017) State obligations to regulate and adjudicate corporate activities under the European Convention on Human rights. EUI Working Paper LAW 2017/15 European University Institute Department of Law Armstrong, Chris (2012) Global Distributive Justice. Cambridge University Press.

BRYSK, A., STOHL, A. (2017) Expanding Human Rights. 21st Century Norms and Governance.

CARMONA CUENCA, E. (2017). "Derechos sociales de prestación y obligaciones positivas del Estado en la jurisprudencia del Tribunal Europeo de Derechos Humanos". Revista de derecho político, ISSN 0211-979X, № 100, 2017 (Ejemplar dedicado a: Monográfico con motivo del XL aniversario de la Constitución Española (I)), págs. 1209-1238

DE SCHUTTER, O. (2011) "The Right of Everyone to Enjoy the Benefits of Scientific Progress and the Right to Food: From Conflict to Complementarity" Human Rights Quarterly, Volume 33, Number 2, May 2011, pp. 304-350 (Article)

EIDE, A. (1995) "The Right to an Adequate Standard of Living including the Right to Food", in Economic, social and cultural rights (Asbjørn Eide, Catarina Krause \& Allan Rosas eds).

FAO (2020) The state of food security and nutrition in the world. Transforming Food Systems for Affordable Healthy Diets http://www.fao.org/publications/ sofi/2020/en/

FAO-VGs (2005) Voluntary Guidelines on the Right to Food. Rome: United Nations Food and Agricultural Organisation. Available at http://www.fao.org/3/a-y7937e.pdf.

FERNÁNDEZ-ALLER, C., coord. (2008) Marco teórico para la aplicación del enfoque basado en derechos humanos en la cooperación para el desarrollo. Ed. Catarata.

FERNÁNDEZ-ALLER, C. (2014) "Los Ombudsman y la exigibilidad de los derechos económicos, sociales y culturales". En Guillermo Escobar, Ombudsman y Democracia. Trama.

GC 12 (1999) General Comment 12, UN Committee on Economic, Social and Cultural Rights Right to Adequate Food (Article 11) E/C.12/1999/5. Available at http:// www.refworld.org/pdfid/4538838c11.pdf. 
GEARTY, C. (2006) Can Human Rights Survive? (Cambridge University Press).

GOIG MARTÍNEZ (2018) “Aproximación a la regulación y contenido del derecho a una alimentación adecuada”, Revista de Derecho UNED, num. 22.

GOLAY, C. (2009) Derecho a la Alimentación y Acceso a la Justicia: Ejemplos a nivel nacional, regional e internacional. FAO.

GREER, S.(2009) "Being "realistic" about human rights". NILQ.

HOSSAIN, N.; LINTELO, D.; WANJIKU KELBERT, A. (2019) “A Common Sense Approach to the Right to Food", Journal of Human Rights Practice, Volume 10, Issue 3, November 2018, Pages 367-387, https://doi.org/10.1093/jhuman/huy028. Published: 09 January 2019.

KING, J. (2012) Judging social rights, p. 318. Cambridge University Press.

KNUTH and VIDAR (2011) Constitutional and Legal Protection of the Right to Food around the World. FAO.

MARTIN, J.; BRAVO, K. (2016) The Business and Human Rights Landscape. Moving Forward, Looking Back. Cambridge University Press

MARTÍN, M.A. AND VIVERO, J.L. (2011) "New Challenges to the Right to Food" CEHAP, Cordoba and Huygens Editorial, Barcelona.

MILLNER, N. (2017) 'The right to food is nature too': food justice and everyday environmental expertise in the Salvadoran permaculture movement. Local Economy, 22(6), 764-783. DOI: 10.1080/13549839.2016.1272560

NARULA, S. (2006) "The Right to Food: Holding Global Actors Accountable Under International Law", 44 Columbia Journal of Transnational Law. 691 https:// digitalcommons.pace.edu/lawfaculty/1112/

NARULA, S. (2013) International Financial Institutions, Transnational Corporations and Duties of States. P. 117. In Malcolm Langford, Wouter Andenhole, Martin Scheinin, Willem van Genugten Global Justice, State Duties, the extraterritorial scope of economic, social and cultural rights in International Law. Cambridge University Press

OKE, E.K. 2020, 'Do agricultural companies that own intellectual property rights on seeds and plant varieties have a right-to-food responsibility?', Science, Technology and Society, vol. 25, no. 1, pp. 142-158. https://doi.org/10.1177/0971721819890043 Digital Object Identifier (DOI): https://doi.org/10.1177/0971721819890043

OSHAUG, BARTH AND EIDE (1994) "Human rights: a normative basis for food and nutrition-relevant policies" Food Policy 199419 (6) 491-516.

PAUPP, TERRENCE E. (2014) Redefining Human Rights in the Struggle for Peace and Development (Cambridge University Press), ISBN: 978-1-107-66931-4, 561 Pages.

ROBINSON, M. (2004) "Advancing Economic, Social, and Cultural Rights: The Way Forward”, 26 Human Rights Quarterly 866, 872 
SMITH-CARRIER, T. ROSS, K.; KIRKHAM, J., AND DECKER PIERCE, B. (2017) "Food is a Right ...Nobody Should Be Starving on Our Streets': "Perceptions of Food Bank Usage in a Mid-Sized City in Ontario, Canada". Journal of Human Rights Practice, 9, 2017, 29-49 doi: 10.1093/jhuman/huw021

SPECIAL RAPPORTEUR ON THE RIGHT TO DEVELOPMENT (2017) World's poor 'paying the price' for global trends

SSENYONJO, M. (2016) Economic, social and cultural rights in international law. Hart Publising.

VALLEDOR ALVAREZ, P. (2013) La protección jurídica del derecho a una alimentación adecuada en España. El papel esencial de las rentas mínimas

VIVERO POH; FERRANDO; DE SCHUTTER; MATEI (2018) Routledge Handbook of Food as Commons. Ed. Routledge.

WARWICK, B.. 'Socio-Economic Rights During Economic Crises: A Changed Approach to Non-Retrogression' (2016) 65(1) International and Comparative Law Quarterly 249.

WERNAART, B.; VAN DER MEULEN, B. (*) (2016) The Right to Food in International Law with Case Studies from the Netherlands and Belgium. Springer International Publishing Switzerland. G. Steier, K.K. Patel (eds.), in International Food Law and Policy, DOI 10.1007/978-3-319-07542-6_4

WESSON, M.(2012) "Enforcing human rights incrementally: review of Jeff King, judging social rights" (Cambridge University Press, 2012) University of Western Sydney Law Review Volume 16.

ZAMBRANO, V.(2019) The right to food: an emerging human rights jurisprudence. Revista General de Derecho Público Comparado 25

ZIEGLER J., GOLAY C., MAHON C., WAY SA. (2011) The Definition of the Right to Food in International Law. In: The Fight for the Right to Food. International Relations and Development Series. Palgrave Macmillan, London. https://doi .org/10.1057/9780230299337_2.

Received: July $3^{\text {rd }} 2020$

Accepted: September $2^{\text {nd }} 2020$ 